\title{
A. Diachkova, A. Kontoboitseva \\ Economic Benefits of gender equality: comparing EU and BRICS countries
}

\section{KEYWORDS}

gender inequality;

gender equality;

equality of men and women;

public welfare;

economic development of the EU

countries;

economic development of the BRICS countries

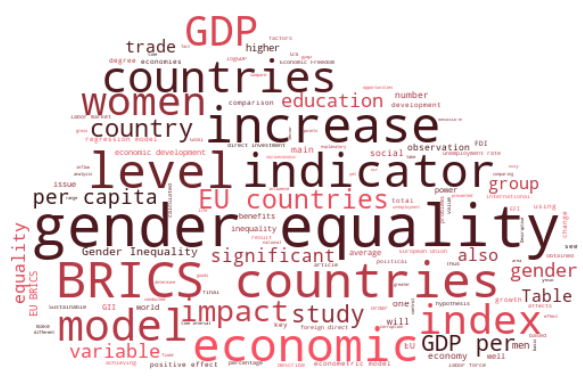

Word Cloud Generated by:

https://wordscloud.pythonanywhere.com/

\section{ABSTRACT}

Introduction. In the modern economy the problems of scientific analysis shift the focus from the subject area of gender inequality to gender equality, and special significance is attached to assessing the impact of gender on the social welfare. At the same time, it is noted that developed and developing countries currently have differences in the quality and quantity of goals achieved to address the issue of gender equality. The aim of the article is to assess the economic benefits of gender equality for a group of countries in the European Union and BRICS.

Materials and methods. Empirical analysis was based on the construction of regression econometric models that assess the impact on the welfare of the country (GDP) of gender equality in combination with basic macroeconomic factors. Fixed effects regression models have the best descriptive capacity for the EU and BRICS countries, which was verified by standard econometric tests.

The information base of the study was made up of official statistics from the reports of the World Bank, the World Economic Forum, the International Monetary Fund, and the United Nations.

Results and Discussion. As a result of the study, it was revealed that the level of gender equality has a positive effect on the economic development of both the EU countries and the BRICS; a comparison of the results of the constructed econometric models for groups of EU and BRICS countries showed that gender equality has a statistically significant impact on the economic development of countries in each group, and in the BRICS countries it is stronger, so with an increase in gender equality by one, GDP per capita increases by 3.4172 vs. 0.4647 in EU countries. The inclusion of key socio-economic indicators in the analysis made it possible to compare the obtained impact, and it was found that the degree of influence of the equality index is not lower than the degree of influence of basic economic indicators. That increases the importance of this problem both at the level of the country and international associations. The conclusions obtained based on the analysis of macro statistics confirmed the conclusions of the researchers based on microeconomic data.

Conclusions. The results of this study are aimed at understanding the problems of gender equality, its impact on the economic well-being of society, both in an individual country and in the world economy as a whole, which can be taken into account in designing the policy of the state and companies that together ensure progress in the development of equality between men and women.

Diachkova, A., \& Kontoboitseva, A. (2022). Economic Benefits of gender equality: comparing EU and BRICS countries. Economic consultant, 37 (5), 4-15. doi: 10.46224/ecoc.2022.1.1 


\section{INTRODUCTION}

In today's reality, the aspect of the impact of gender equality or inequality on the development of both national economies and the world economy is becoming more relevant. Many countries note and quantify the degree of gender differences and gaps in economic activity.

Resent researches recognize that gender is a major objective marker of socioeconomic stratification at times. Regardless of one's socioeconomic group, there are systematic gender differences in material well-being, although the degree of inequality varies between countries and over time. As a result, gender inequality is a feature of most societies, with men, on average, better positioned in social, economic, and political hierarchies.

Achieving gender equality over the past twenty years is considered one of the main goals for organizations and governments around the world, which seek to create and consolidate socio-economic structures that will contribute to the development of society [1, p. 1], which determines the subject area of the study of this issue in this article.

The present situation in the world shows that objectively men tend to do less housework and child care, but make key household decisions, own a larger sector of public power influence, have higher salaries and are in greater numbers in leadership positions, and more often have greater control over economic goods [2, p. 2] than women in every country. But there is no denying that new trends of systematic change are also evident. For example, young fathers are more active in taking care of their children, mothers are the main breadwinners even when fathers are around, and men have a work-life balance policy.

It should be emphasized that gender equality is one of the Sustainable Development Goals proposed by the UN. The fifth Sustainable Development Goal postulates gender equality and the empowerment of all women and girls [3]. The Gender Equality Index, presented by the European Union, tracks and reports on progress in reducing gender disparities in social, economic and political spheres, offering yet comprehensive measures, measuring equality between men and women in six main areas (work, money, knowledge, time, effort and health), called "domains" and two additional (violence against women and intersecting inequalities) [4]. The index reveals both successes and failures on this issue, and explores what can be done to seize opportunities for change.

In this regard, it is relevant not just to understand equality in order to solve social problems, but also how increasing equality has an impact on the economic well-being of the country. The aim of this article is to assess the economic benefits of gender equality for the European Union (hereafter, the EU) and the BRICS countries. 


\section{MATERIALS AND METHODS}

In the study of issues related to the impact of gender equality on the economic development of countries will be based on the models of E. V. Rodriguez, A. Mitra. Rodriguez's research is based on the degree of inequality determined through the standard deviation, as a result it was found that a decrease in inequality of opportunities increases GDP growth by 1.3 percentage points, and an increase in equality increases economic growth on average about 1.2 percentage points [5, p. 2]. A. Mitra's study proved that the feminization of the labor force has a positive relationship with economic growth in Latin American countries [6, p. 82].

Based on the models developed by economic science, this article chooses GDP per capita as the dependent variable as an indicator of economic development of countries. To describe the impact of gender equality on GDP, the Gender Inequality Index, recalculated as an inverse relationship, is taken. This index takes a value from 0 to 1 , the closer to one, the higher is the level of inequality. Consequently, the level of gender equality can be calculated by subtracting the value of this index from 1. In order to make the explanatory power of the model of gender equality impact on the economy higher, as well as to reveal the degree of gender equality impact in comparison with the key economic factors, the following variables were included in the econometric equation:

- GDP (GDP per capita) - the dependent variable, GDP per capita in US dollars, which determines the level of economic development of the country [7];

- Gll (Gender Inequality index) - Gender Equality Index, designed to measure gender homogeneity in access to resources and opportunities in individual countries, recalculated in inverse relation to the Gender Inequality Index. Thus, the higher the index, the higher the gender equality in the country [8];

- unemployment(Unemployment, \% of total labor force)-an indicator of the unemployment rate, measured as a percentage of the total labor force, a national estimate [7];

- CC (Control of Corruption) is an indicator of the control of corruption, reflecting the perception of the extent to which state power is used for personal gain, including both small and large forms of corruption, as well as the "capture" of the state by elites and private interests. The score is given by the country's aggregate index in units of a standard normal distribution, i.e., in the range of approximately - 2.5 to 2.5 [7];

- EFI (Economic Freedom Index) is an index of economic freedom, calculated by The Heritage Foundation together with The Wall Street Journal. It is measured in the range from 0 to 100 . The closer to 100 , the more economically free the country is;

- GCF (Gross capital formation) is an indicator of gross capital formation, which consists of the cost of adding to the fixed assets of the economy plus the net change in the level of stocks (the goods that firms hold to meet temporary or unexpected fluctuations in production or sales) [7]; 
- FDI (Foreign Direct Investments, net inflows) - the inflow of foreign direct investment in U.S. dollars [7];

- education (Educational attainment, at least completed upper secondary) - an indicator of the level of education, at least completed upper secondary [7];

- trade (Trade) - an indicator of international trade, the sum of exports and imports of goods and services [7].

The information base of the study is represented by official statistical data from the reports of the World Bank, the World Economic Forum, the International Monetary Fund, and the United Nations.

The main hypothesis of the study is that gender equality has a positive effect on GDP per capita.

\section{RESULTS}

The conducted comparative analysis of equality issues allows us to conclude that the degree of relevance of certain gender equality problems at the moment is different in the $\mathrm{EU}$ and in the BRICS countries. For the EU at the moment, there are virtually no problems that some of the BRICS countries have not yet coped with (the ban on participation in the country's economic activity, decriminalization of domestic violence [9], barriers for women to receive treatment and prevention of HIV infections, child marriage [2]). For the EU, some of the main objectives are to achieve parity of political representation, to promote more women in the labor market, and to close the pay gap for women. Of course, these goals should also be achieved by the BRICS countries, along with the solution of the above-mentioned problems for this group of countries. The BRICS countries are very diverse, but they have one thing in common: the pursuit of sustainable macroeconomic growth through economic cooperation, peace and security, social justice, sustainable development and improved quality of life.

Let's compare elements of gender equality using the Gender Inequality Index (GII) and determine which group of countries has a smaller gender gap on these indicators.

The Gender Inequality Index (GII) reflects gender inequality in three dimensionsreproductive health, empowerment, and the labor market. It ranges from 0 , when women and men live equally, to 1 , when there is complete gender inequality. The Gll is calculated using an association-sensitive measure of inequality, which implies that the index is based on the overall average of the total values of the different orders-the first aggregation being the geometric average across the dimensions. These averages, calculated separately for women and men, are aggregated using the harmonic mean by sex (see Figure 1). 
MEASUREMENTS

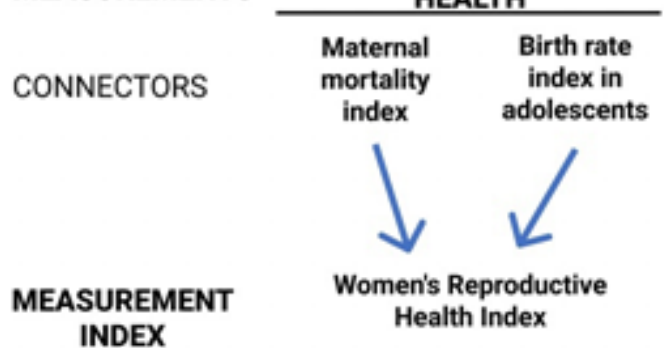

INDEX

\section{HEALTH}

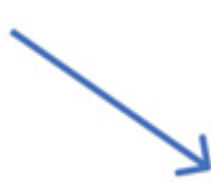

EMPOWERMENT

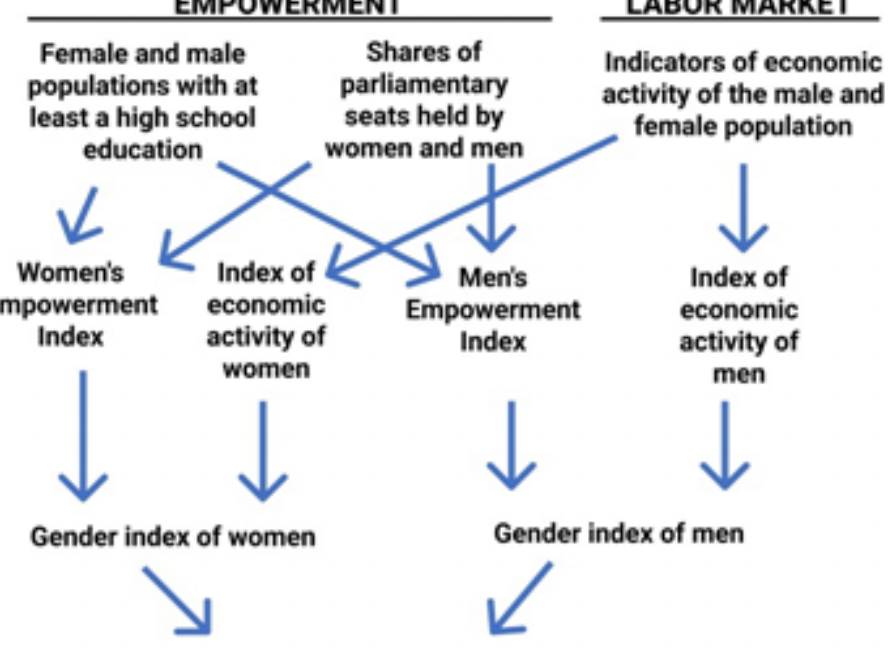

Gender Equality Index (GII)

Figure 1 Algorithm of calculating the gender equality index*

* compiled by the authors according to [8].

Let us consider and compare between groups of countries the indicators that can describe gender inequality on their own.

proportion of seats in parliament held by women

completed high school education for women

economic activity of women in the labor market

maverage for BRICS countries, \%

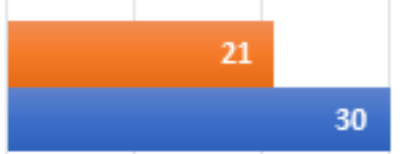

Figure 2 Gender Equality Indicators in the EU and BRICS*

* compiled by the authors according to [7; 11]

Comparing the data in Figure 2, we see that women from the EU countries have a higher proportion of seats in parliaments than women in the BRICS countries, yet the percentage of women in parliament is very low in both groups of countries. The UN study points out that objectively and traditionally women are less likely to enter the political sector, so their share is small.

In the EU there are 6 p.p. more economically active women in the labor market than in the BRICS countries. In both groups of countries the number of men in the labor force exceeds the number of women, with an $8 \%$ increase in the EU and a $20 \%$ increase in the BRICS countries. 
Thus, comparing the three indicators of gender equality, we see that two of them are weaker in the BRICS countries than in the EU. Access to education for women is at the same level in both groups and very close to gender parity. The advanced level of gender equality in the EU may explain the fact that these countries have more developed economies than the BRICS countries, as the level of gender equality has a direct impact on the economy.

For the EU and the BRICS countries there are different primary challenges to achieving gender equality, but this does not prevent us from assessing how it affects the economies of the countries. It is also understandable that although each of the BRICS countries has its own national characteristics related to its historical past and cultural background, and their performance may differ, averages may well describe the overall picture for developing countries.

However, other economic and socio-economic key factors, in addition to gender equality, can influence the economy, so let's conduct an econometric study.

Let's make a model to estimate the economic benefits for the countries of the European Union. The number of countries (observations) - 28. The time interval is from 2009 to 2018. The number of observations for each country is distributed evenly over the years. A total of 280 observations were obtained, which formed the basis of the study (see Table 1).

Table 1

Descriptive statistics for EU countries

\begin{tabular}{|c|c|c|c|c|c|c|c|}
\hline Variable & & Mean & Std. Dev. & Min & Max & Obser & ions \\
\hline $\log G D P$ & $\begin{array}{l}\text { overall } \\
\text { between } \\
\text { within }\end{array}$ & 10.21097 & $\begin{array}{l}.6359047 \\
.6399955 \\
.0894049\end{array}$ & $\begin{array}{r}8.83102 \\
8.938379 \\
9.984829\end{array}$ & $\begin{array}{r}11.6854 \\
11.60012 \\
10.5233\end{array}$ & $\begin{array}{l}\mathrm{N}= \\
\mathrm{n}= \\
\mathrm{T}=\end{array}$ & $\begin{array}{r}280 \\
28 \\
10\end{array}$ \\
\hline unempl t & $\begin{array}{l}\text { overall } \\
\text { between } \\
\text { within }\end{array}$ & 9.392816 & $\begin{array}{l}4.701432 \\
4.057655 \\
2.483951\end{array}$ & $\begin{array}{r}2.2433 \\
5.1998 \\
-1.771884\end{array}$ & $\begin{array}{r}27.4662 \\
20.85993 \\
16.83388\end{array}$ & $\begin{array}{l}\mathrm{N}= \\
\mathrm{n}= \\
\mathrm{T}=\end{array}$ & $\begin{array}{r}280 \\
28 \\
10\end{array}$ \\
\hline EFI & $\begin{array}{l}\text { overall } \\
\text { between } \\
\text { within }\end{array}$ & 69.08071 & $\begin{array}{l}5.703239 \\
5.527931 \\
1.718912\end{array}$ & $\begin{array}{r}53.2 \\
56.98 \\
63.43071\end{array}$ & $\begin{array}{r}82.2 \\
78.2 \\
75.13071\end{array}$ & $\begin{array}{l}\mathrm{N}= \\
\mathrm{n}= \\
\mathrm{T}=\end{array}$ & $\begin{array}{r}280 \\
28 \\
10\end{array}$ \\
\hline GCF & $\begin{array}{l}\text { overall } \\
\text { between } \\
\text { within }\end{array}$ & 21.12264 & $\begin{array}{r}3.61403 \\
2.95832 \\
2.142865\end{array}$ & $\begin{array}{r}10.21701 \\
13.4119 \\
14.44412\end{array}$ & $\begin{array}{r}37.41433 \\
26.33028 \\
34.9287\end{array}$ & $\begin{array}{l}\mathrm{N}= \\
\mathrm{n}= \\
\mathrm{T}=\end{array}$ & $\begin{array}{r}280 \\
28 \\
10\end{array}$ \\
\hline FDI & $\begin{array}{l}\text { overall } \\
\text { between } \\
\text { within }\end{array}$ & 11.03536 & $\begin{array}{r}32.86944 \\
27.3758 \\
18.84518\end{array}$ & $\begin{array}{r}-41.5082 \\
-.018818 \\
-109.9073\end{array}$ & $\begin{array}{l}280.1318 \\
141.8014 \\
149.3658\end{array}$ & $\begin{array}{l}\mathrm{N}= \\
\mathrm{n}= \\
\mathrm{T}=\end{array}$ & $\begin{array}{r}280 \\
28 \\
10\end{array}$ \\
\hline trade & $\begin{array}{l}\text { overall } \\
\text { between } \\
\text { within }\end{array}$ & 125.7187 & $\begin{array}{l}70.31516 \\
70.34864 \\
12.44721\end{array}$ & $\begin{array}{l}45.41876 \\
54.93192 \\
61.12163\end{array}$ & $\begin{array}{r}408.362 \\
360.5699 \\
173.5108\end{array}$ & $\begin{array}{l}\mathrm{N}= \\
\mathrm{n}= \\
\mathrm{T}=\end{array}$ & $\begin{array}{r}280 \\
28 \\
10\end{array}$ \\
\hline educat $n$ & $\begin{array}{l}\text { overall } \\
\text { between } \\
\text { within }\end{array}$ & 68.89341 & $\begin{array}{l}16.65752 \\
16.81486 \\
1.963183\end{array}$ & $\begin{array}{r}21.02282 \\
23.15329 \\
58.7259\end{array}$ & $\begin{array}{l}89.70639 \\
87.73571 \\
80.62236\end{array}$ & $\begin{array}{l}\mathrm{N}= \\
\mathrm{n}= \\
\mathrm{T}=\end{array}$ & $\begin{array}{r}280 \\
28 \\
10\end{array}$ \\
\hline$c \mathrm{C}$ & $\begin{array}{l}\text { overall } \\
\text { between } \\
\text { within }\end{array}$ & 1.00555 & $\begin{array}{l}.7933567 \\
.7989845 \\
.1078492\end{array}$ & $\begin{array}{r}-.2672882 \\
-.2105742 \\
.6856533\end{array}$ & $\begin{array}{r}2.446495 \\
2.3026 \\
1.322111\end{array}$ & $\begin{array}{l}\mathrm{N}= \\
\mathrm{n}= \\
\mathrm{T}=\end{array}$ & $\begin{array}{r}280 \\
28 \\
10\end{array}$ \\
\hline GII & $\begin{array}{l}\text { overall } \\
\text { between } \\
\text { within }\end{array}$ & .8651429 & $\begin{array}{l}.0713915 \\
.0696317 \\
.0201139\end{array}$ & $\begin{array}{r}.635 \\
.6551 \\
.7881429\end{array}$ & $\begin{array}{r}.96 \\
.9536 \\
.9266429\end{array}$ & $\begin{array}{l}\mathrm{N}= \\
\mathrm{n}= \\
\mathrm{T}=\end{array}$ & $\begin{array}{r}280 \\
28 \\
10\end{array}$ \\
\hline
\end{tabular}


To identify the best model, we conducted a Hausman test to compare regression models with random and fixed effects. This test showed that the regression model with fixed effects is superior to the regression model with random effects.

The final econometric model and significant explanatory variables for EU countries are presented in Table 2. In order to see a more correct model, the absolute indicator is converted to the relative logGDP, using logarithm.

Table 2

Final econometric model for EU countries

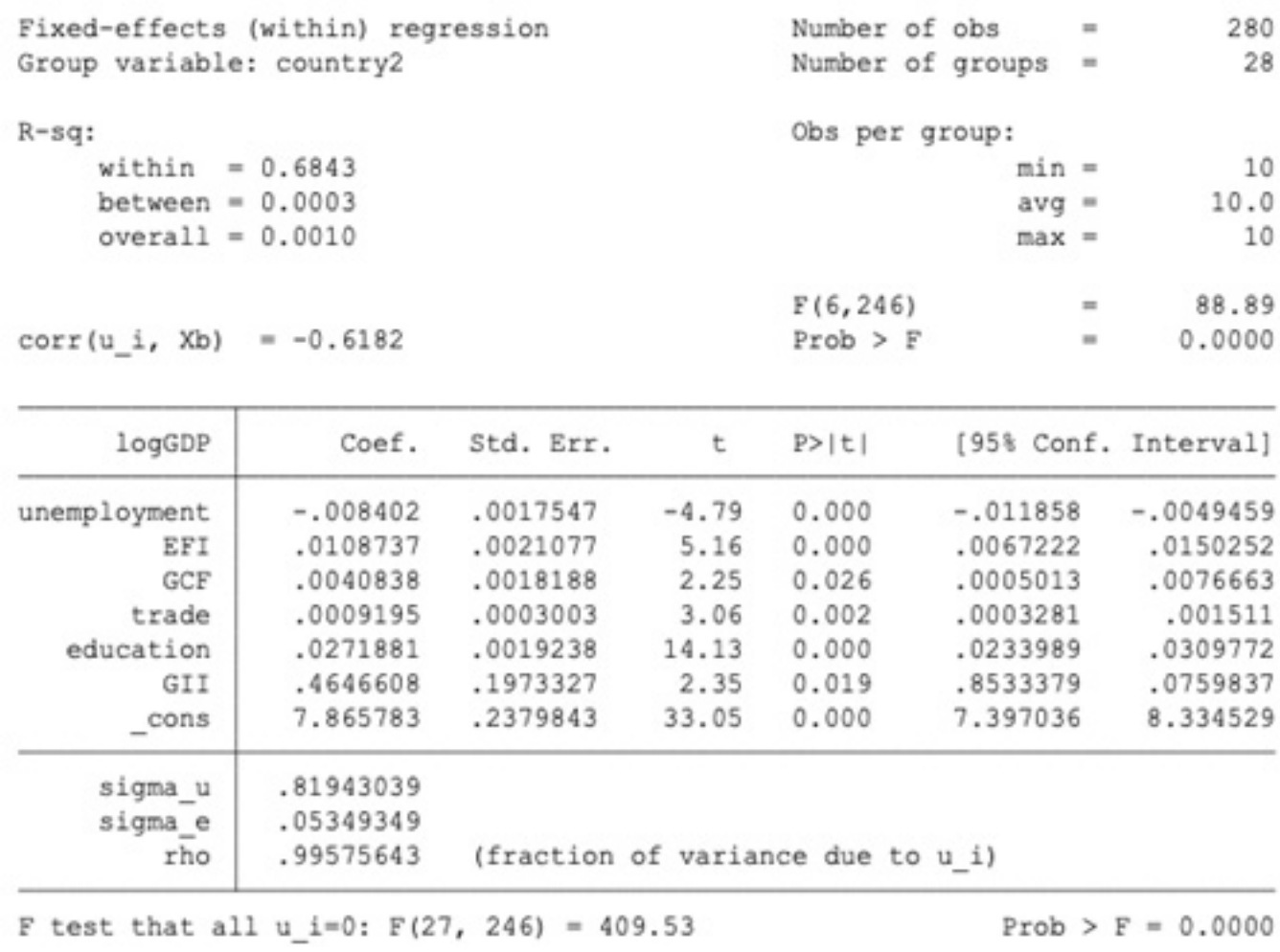

In accordance with the obtained econometric model the main hypothesis for the EU countries is proved, testing that the level of gender equality (GGI indicator) has a positive effect on GDP per capita.

The interpretation of the regression model looks like this: with the increase of Gll per unit GDP per capita will increase by 0.4647 . In addition, the model showed the level of influence of other factors on the economic development of countries. Thus, an increase in the unemployment rate has a negative impact on GDP. It was obtained that with increase of unemployment rate by 1 , GDP falls by 0.0084 . If the level of economic freedom (EFI) increases by 1, GDP per capita (GDP) will increase by 0.0109. If the level of gross savings (GCF) increases by 1, GDP per capita will increase by 0.0041 . When the level of international trade increases by 1, GDP also increases by 0.0009 . Finally, the education indicator (education), which if increased by 1 , provides an increase in GDP by 0.0272 .

Now let's make a model for estimating economic benefits for the BRICS countries. The time interval of observation is one year. The number of countries (observations) is five. The 
time interval is from 2009 to 2018 . The number of observations for each country is distributed evenly over the years. A total of 50 observations were obtained, which formed the basis of the study. Using logarithm, the absolute indicator, which does not take a negative value of GDP, was converted into a relative logGDP to create a correct model.

Table 3

Descriptive statistics for EU countries

\begin{tabular}{|c|c|c|c|c|c|c|c|}
\hline \multicolumn{2}{|l|}{ Variable } & \multirow{2}{*}{$\begin{array}{r}\text { Mean } \\
8.711203\end{array}$} & \multirow{2}{*}{$\begin{array}{l}\text { Std. Dev. } \\
.7564186 \\
.8066639\end{array}$} & Min & $\operatorname{Max}$ & \multicolumn{2}{|c|}{ Observations } \\
\hline $\log G D P$ & $\begin{array}{l}\text { overall } \\
\text { between }\end{array}$ & & & $\begin{array}{r}7.004847 \\
7.34527\end{array}$ & $\begin{array}{l}9.680787 \\
9.361139\end{array}$ & $\begin{array}{l}\mathrm{N}= \\
\mathrm{n}=\end{array}$ & $\begin{array}{r}50 \\
5\end{array}$ \\
\hline & within & & .2024353 & 8.150827 & 9.086782 & $T=$ & 10 \\
\hline \multirow[t]{2}{*}{ unempl t } & $\begin{array}{l}\text { overall } \\
\text { between }\end{array}$ & 10.25732 & $\begin{array}{l}7.857994 \\
8.571972\end{array}$ & $\begin{array}{r}3.8 \\
4.052\end{array}$ & $\begin{array}{r}27.0354 \\
25.26513\end{array}$ & $\begin{array}{l}\mathrm{N}= \\
\mathrm{n}=\end{array}$ & $\begin{array}{r}50 \\
5\end{array}$ \\
\hline & within & & 1.328705 & 8.041169 & 14.20237 & $T=$ & 10 \\
\hline \multirow[t]{3}{*}{ EFI } & overall & 55.712 & 4.15823 & 50.3 & 63.8 & $\mathrm{~N}=$ & 50 \\
\hline & between & & 4.087459 & 52.31 & 62.61 & $\mathrm{n}=$ & 5 \\
\hline & within & & 1.911085 & 51.262 & 61.602 & $T=$ & 10 \\
\hline \multirow[t]{2}{*}{$\mathrm{GCF}$} & overall & 28.5836 & 10.96216 & 14.63039 & 47.81881 & $\mathrm{~N}=$ & 50 \\
\hline & $\begin{array}{l}\text { between } \\
\text { within }\end{array}$ & & $\begin{array}{l}11.83267 \\
2.423514\end{array}$ & $\begin{array}{r}18.79241 \\
23.6817\end{array}$ & $\begin{array}{l}46.26974 \\
33.68998\end{array}$ & $\begin{array}{l}\mathrm{n}= \\
\mathrm{T}=\end{array}$ & $\begin{array}{r}5 \\
10\end{array}$ \\
\hline \multirow[t]{2}{*}{ FDI } & overall & 2.236085 & 1.050673 & .4789174 & 4.145494 & $\mathrm{~N}=$ & 50 \\
\hline & $\begin{array}{l}\text { between } \\
\text { within }\end{array}$ & & $\begin{array}{l}.8456603 \\
.7211971\end{array}$ & $\begin{array}{l}1.294391 \\
.6129566\end{array}$ & $\begin{array}{l}3.511584 \\
3.681233\end{array}$ & $\begin{array}{l}\mathrm{n}= \\
\mathrm{T}=\end{array}$ & $\begin{array}{r}5 \\
10\end{array}$ \\
\hline \multirow[t]{2}{*}{ trade } & $\begin{array}{l}\text { overall } \\
\text { between }\end{array}$ & 44.96004 & $\begin{array}{l}12.11981 \\
12.71543\end{array}$ & $\begin{array}{l}22.10598 \\
24.96111\end{array}$ & $\begin{array}{r}64.4345 \\
60.07953\end{array}$ & $\begin{array}{l}\mathrm{N}= \\
\mathrm{n}=\end{array}$ & $\begin{array}{r}50 \\
5\end{array}$ \\
\hline & within & & 3.860595 & 37.52512 & 53.15995 & $T=$ & 10 \\
\hline \multirow[t]{3}{*}{ echucat $\sim \mathrm{n}$} & overall & 46.31811 & 22.90362 & 20.647 & 86.135 & $\mathrm{~N}=$ & 50 \\
\hline & between & & 25.29918 & 23.881 & 85.11542 & $\mathrm{n}=$ & 5 \\
\hline & within & & 1.444792 & 42.80414 & 49.05824 & $\mathrm{~T}=$ & 10 \\
\hline \multirow[t]{3}{*}{$\mathrm{CC}$} & overall & -.3872276 & .3627927 & -1.132048 & .1821967 & $\mathrm{~N}=$ & 50 \\
\hline & between & & .3707014 & -.9771873 & .0228374 & $\mathrm{n}=$ & 5 \\
\hline & within & & .1394249 & -.714574 & -.0165989 & $\mathrm{~T}=$ & 10 \\
\hline \multirow[t]{2}{*}{ GII } & overall & .62064 & .1358184 & .371 & .837 & & 50 \\
\hline & between & & $\begin{array}{r}-1475778 \\
0258398\end{array}$ & $\begin{array}{r}-4335 \\
55674\end{array}$ & $\begin{array}{r}.8212 \\
68614\end{array}$ & $\begin{array}{l}\mathrm{n}= \\
\mathrm{T}=\end{array}$ & $\begin{array}{r}5 \\
10\end{array}$ \\
\hline
\end{tabular}

The selected final regression equation, verified on the basis of comparison with other constructed econometric models, is presented in Table 4.

The model for the BRICS countries also confirmed the main hypothesis. As in the EU countries, the level of gender equality has a positive effect on the economic development of the countries. When the GGI indicator reflecting gender equality increases, GDP per capita (GDP) will increase by 3.4172. The indicator of foreign direct investment (FDI) also affects the indicator of GDP, increasing FDI by 1, GDP increases by 0.1567 .

The indicator of world trade (trade) negatively affects, if it increases by 1 , the GDP per capita will change by 0.0302 , this can be explained by the fact that in this indicator for the BRICS countries a large share is imports, which does not lead to an increase in GDP. The education indicator, which describes the level of education, has a positive effect on GDP, with an increase of 1 , GDP rises by 0.0208 . 
Table 4

Final econometric model for the BRICS countries

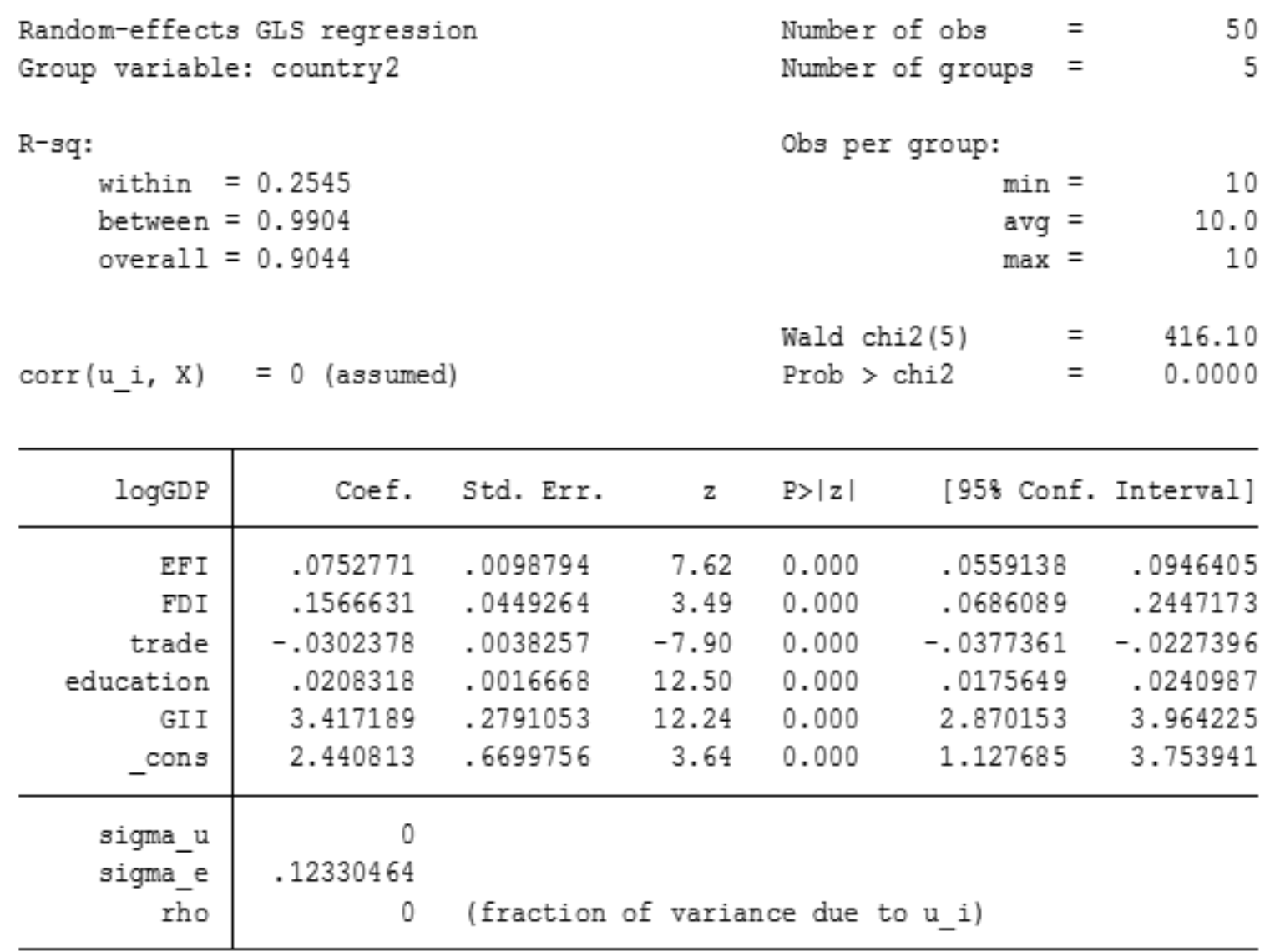

We present a comparison of the significance of the variables for the models of the impact of gender equality on the EU and BRICS economies in the table below.

Table 5

Comparison of the significance of variables for regression models of the impact of gender equality on the EU and BRICS economies

\begin{tabular}{|c|c|c|}
\hline & EU & BRICS \\
\hline Variables & $\log$ GDP & $\operatorname{logGDP}$ \\
\hline unemployment & $-0.0084^{* * *}$ & \\
\hline EFI & $0.0109^{* * *}$ & $0.0753^{* * *}$ \\
\hline GCF & $0.0041^{* *}$ & $0.1567^{* * *}$ \\
\hline FDI & & $-0.0302^{* * *}$ \\
\hline trade & $0.0009^{* * *}$ & $0.0208^{* * *}$ \\
\hline education & $0.0272^{* * *}$ & \\
\hline CC & & $3.4172^{* * *}$ \\
\hline GII & $0.4647^{* *}$ & 0.2545 \\
\hline $\mathrm{R}^{2}$ & 0.6843 & \\
\hline
\end{tabular}

** the coefficient is statistically significant at $10 \%$ level

*** the coefficient is statistically significant at the $5 \%$ level 


\section{DISCUSSION}

An empirical study aimed at assessing the economic benefits of equality in the country covered a comparison of the European Union and the BRICS countries. The hypothesis of a positive effect of equality on country welfare was confirmed by regression analysis.

In our study we agree with the approach of Madhavi P. [10] those additional independent variables - key socioeconomic factors - should be included in the analysis. This is what allows us to increase the descriptive power of the model. We focused on the benefits of gender equity which is consistent with Damjanovic \& Selvaretnam research. Their simulation model shows that in the long run, an economy with gender equality can outperform an economy where gender balance of power maximizes social output [12].

The conclusions of our model confirm the theoretical and empirical microeconomic models in the labor market slice conducted by Roshchin [13], and indicate the provision of conditions for equality among men and women in the economic life of the country.

\section{CONCLUSION}

Thus, comparing the results of the models for the groups of EU and BRICS countries, it can be noted that gender equality has an impact on the economic development of countries in each group, with a stronger impact in the BRICS countries. For example, when this indicator increases by one, GDP per capita increases by 3.4172 versus 0.4647 in the EU countries. This variable is significant at all levels for the BRICS countries, while for the EU countries only at the levels of $5 \%$ and $10 \%$. The higher role of gender equality for the BRICS may be due to the fact that the EU is stronger in achieving equality and therefore the positive impact is not as significant as for the BRICS countries. Consequently, the issue of achieving gender equality should be more acute for the BRICS countries.

Also, the common significant variables were the Economic Freedom Index (EFI), the level of international trade (trade), and the level of education (education); they are significant at all levels for EU countries and for the BRICS countries. In the model for the EU countries the unemployment rate was also significant at all levels, which negatively affects GDP, and in the model for the BRICS countries another significant indicator at all levels is FDI, which explains the inflow of foreign direct investment, the more of it, the higher GDP. The explanatory power is greater in the model for the EU countries.

The article tested how important it is to take measures to ensure gender equality in key policy areas to enhance economic growth, reduce losses and not worsen the gender gap.

It is worth noting that addressing this issue implies very significant economic as well as social benefits for the whole society in both BRICS and EU countries. Promoting change and building new coalitions between governments, the social sector and companies are necessary to achieve gender equality. 


\section{REFERENCES}

1. Serrano, C.C. (2014). What is gender inequality? The Tavistock Institute, 5.

2. Society does not stand on the side of girls. UNAIDS. Available at: www.unaids.org/ ru/resources/presscentre/featurestories/2019/march/20190318_riseclubs (accessed 10 Janiary 2021).

3. Official website of the United Nations, Sustainable Development Goals. Available at: www.un.org/sustainabledevelopment/ru/sustainable-development-goals/ (accessed 10 Janiary 2021).

4. Gender Equality and Women's Development in China. Available at: www.china-un.ch/ eng/rqrd/jblc/t210715.htm (accessed 10 Janiary 2021).

5. Mitra, A., Bang, J. \& Biswas, A. (2015). Gender Equality and Economic Growth: Is it Equality of Opportunity or Equality of Outcomes? Feminist Economics, 21, 5.

6. Vøsconez, A. R. (2017). Economic growth and gender inequality: an analysis of panel data for five Latin American countries. CEPAL Review, 122, 81-96

7. The World Bank. Available at: https://datacatalog.worldbank.org/home (accessed 10 Janiary 2021).

8. Smarter, greener, more inclusive? Indicators to support the Europe 2002 strategy. Available at: www.ec.europa.eu/eurostat/documents/3217494/10155585/KS-04-19559-EN-N.pdf/b8528d01-4f4f-9c1e-4cd4-86c2328559de (accessed 10 Janiary 2021).

9. Criminal Code of the Russian Federation from 13.06.1996 No. 63-FZ (ed. from 12.11.2018). Legislative Assembly RF.17.06.1996. no 25. 2954 p.

10. Madhavi, P. (2016). Study and Analysis of Certain Parameters in BRICS Countries. IOSR Journal of Humanities and Social Science, 21, 48-52

11. European Institute for Gender equality, Gender Equality Index 2019 Highlights. Available at: www.eige.europa.eu/publications/gender-equality-index-2019-report/highlights (accessed 10 Janiary 2021).

12. Damjanovic, T., \& Selvaretnam, G. (2020). Economic growth and evolution of gender equality. The manchester school, 88(1), 1-36.

13. Roshchin, S. Y., Zubarevich, N. V. (2005). Gender equality and empowerment of women in Russia in the context of the Millennium Development Goals. Office of the UN System Permanent Coordinator in the RF, 30.

14. Morais Maceira, H. (2017). Economic Benefits of Gender Equality in the EU. Intereconomics, 52, 178-183. DOI: 10.1007/s10272-017-0669-4

15. Osyrio, A. (2019). Gender differences in competition: gender equality and cost reduction policies. Rev Econ Design, 23, 27-52. DOI: 10.1007/s10058-019-00219-x

16. Frigo, A., Roca Fernбndez, И. (2022). Roots of gender equality: the persistent effect of beguinages on attitudes toward women. J Econ Growth, 27, 91-148. DOI: 10.1007/ s10887-021-09198-7 
17. Bando, R., Berlinski, S. \& Carrasco, J. M. (2019). Progress and Challenges for an EvidenceBased Gender Equality Policy: a Focus in Latin America and the Caribbean. J Econ Race Policy, 2, 187-201. DOI: 10.1007/s41996-019-00034-0

18. Gunnarsson, E., \& Spangenberg, U. (2019). Gender Equality and Taxation Policies in the EU. Intereconomics, 54, 141-146. DOI: 10.1007/s10272-019-0812-5

19. Profeta, P. (2017). Gender Equality in Decision-Making Positions: The Efficiency Gains. Intereconomics, 52, 34-37. DOI: 10.1007/s10272-017-0640-4

20. Hupkau, C., \& Ruiz-Valenzuela, J. (2021). Work and children in Spain: challenges and opportunities for equality between men and women. SERIEs. DOI: 10.1007/s13209021-00243-7

21. Santos Silva, M., Klasen, S. (2021). Gender inequality as a barrier to economic growth: a review of the theoretical literature. Rev Econ Household, 19, 581-614. DOI: 10.1007/ s11150-020-09535-6

\section{INFORMATION ABOUT THE AUTHORS}

1. Anna V. Diachkova (Russia, Ekaterinburg) - Associate Professor, PhD in Economics, Associate Professor of the Department of Economic Theory and Economic Policy. Ural Federal University named after the first President of Russia B.N. Yeltsin. E-mail: a.v.diachkova@urfu.ru. ORCID ID: 0000-0003-4970-1820. Scopus Author ID: 57211156711

2. Anna E. Kontoboitseva (Russia, Ekaterinburg) - Student. Ural Federal University named after the first President of Russia B.N. Yeltsin. E-mail: iamkontoboitseva@gmail.com 